\title{
S7 - Adherencia al tratamiento nutricional en pacientes con diabetes mellitus tipo 2 que asisten a un programa educativo
}

\author{
Mariela A. Carvajal \\ Maestría en Alimentación y Nutrición, Universidad de San Carlos de Guatemala
}

*Autor al que se dirige la correspondencia: licda.mariela.carvajal@gmail.com

\section{Resumen}

Q 1 objetivo de este estudió fue evaluar la adherencia al tratamiento nutricional por medio de la hemoglobina glicosilada en pacientes con diabetes mellitus tipo 2 que asistieron a un programa educativo en diabetes en la ciudad de Guatemala, así como evaluar los principales factores que influyen en ella. Se realizó un estudio de tipo prospectivo, longitudinal, experimental, pareado de intervención no medicamentosa. Se utilizó la prueba de Morinsky-Green Levine para evaluar la adherencia al tratamiento nutricional, el cual consiste en cuatro preguntas de auto informe sobre la adherencia. La muestra estuvo conformada por 126 pacientes que recibieron una intervención educativa durante cinco meses. La metodología utilizada permitió analizar la adherencia al tratamiento por medio de la prueba de hemoglobina glicosilada, una encuesta de adherencia, evaluación del consumo por grupos de alimentos al inicio y al final. Uno de los principales hallazgos fue que los pacientes están convencidos que su plan nutricional les beneficia y les evitaría complicaciones. El apoyo familiar también juega un papel muy importante en la adherencia de estos pacientes al tratamiento nutricional. Los indicadores de adherencia que se encontraron más afectados son los relacionados al costo del plan de alimentación y la dificultad para seguirlo. Se concluye que es posible utilizar la hemoglobina glicosilada como un indicador efectivo de adherencia, ya que el porcentaje de pacientes con hemoglobina glicosilada controlada aumentó de un 50 a un $65.9 \%$ después de la intervención.

Palabras claves: Plan educativo, hemoglobina glicosilada, intervención educativa

\begin{abstract}
$\mathrm{T}$ he aim of this studied was to assess the adherence to a nutritional treatment by glycosylated hemoglobin in patients with Diabetes Mellitus Type 2 who attended a diabetes education program in the capital city as well as assess the main factors that influence it. To do this a prospective, longitudinal, experimental, non-drug intervention couplet was performed. The test of Morinsky Green Levine to assess adherence to nutritional therapy, which consists of four questions self report on adherence was used. The sample consisted of 126 patients that received an educational intervention for five months. The methodology allowed us to analyze adherence to treatment through glycosylated hemoglobin test, a survey of adhesion, evaluation of consumption by food groups at the beginning and end. One of the main findings was that patients are convinced that their nutritional plan benefits them and prevent them complications. Family support also plays a major role in these patients adherence to nutritional therapy role. Adherence indicators that were found most affected are those related to the cost of eating plan and the difficulty to follow. It is concluded that it is possible to use the glycosylated hemoglobin as an effective indicator of adhesion as the percentage of patients with controlled glycosylated hemoglobin increased from 50 to $65.9 \%$ postoperatively.
\end{abstract}

Keywords: Educational plan, glycosylated hemoglobin, educative intervention 